\title{
Design, Implementation and Students' Emotional Assessment of a Software for the Learning of Rational Numbers through Music Metaphors in Chilean Primary Education: An Exploratory Study on Audio Fractions
}

\author{
Tomás Thayer ${ }^{\mathrm{a}}$, M. Alicia Venegas-Thayer ${ }^{\mathrm{b}}$, and Jesús Tejada ${ }^{\mathrm{c}}$ \\ Corresponding author: Jesús Tejada (jesus.tejada@uv.es) \\ a Universidad Metropolitana de Ciencias de las Educación. Santiago. Chile (ORCID ID: 0000-0003-3987-3952) \\ bPontificia Universidad Católica de Valparaíso, Chile \\ ${ }^{c}$ Universidad de Valencia, Spain (ORCID ID: 0000-0003-0532-3960)
}

Keywords: mathematical teaching-learning, music and sound metaphors, educational software, fractions and rational numbers, emotional assessment.

International Journal of Innovation in Science and Mathematics Education, 27(2), 1-17, 2019

\begin{abstract}
Using sound and music as a metaphor to approach curricular mathematical contents in Primary Education seems an interesting field that deserves some research. Both music and sound can synergically act as scaffolding for learning, intervening as part of situated knowledge, and they could offer a new perspective for learning mathematics at schools, giving pupils opportunities to develop their own mental representations. Also, the incorporation of an affective/emotional analysis, as criteria for evaluation, seems pertinent and complementary to other criteria in the production of multimedia material with educational purposes both in formal and non-formal domains of education. These are the intentions of the present work, which shows the design, implementation and assessment of AudioFractions, as part of an educational software package called Sound Interactive MusicMathematics, which was conceived to aid mathematical learning through sound and music in Chilean Primary Education. The investigation was carried out in a three-stage design: 1) generate significant metaphors; 2) implement and test functional software prototypes and didactic guidelines; and 3) assess the software. Pupils in risk of social exclusion at three priority public schools in Santiago de Chile ( $\mathrm{N}=137$; $9-11$ years old) were subjected to AudioFractions in one 60-minute session. Then, students filled a questionnaire validated by experts with their perceptions about the software and their emotions. Results of the four assessment variables (global, technical, mathematical, musical) plus an affective-emotional assessment, show an excellent reception of AudioFractions.
\end{abstract}

\section{Introduction}

In the 99' Trends in International Mathematics and Science Study (TIMSS), mathematic classes from seven countries were video recorded. Analysis of these videos reveals the existence of a national pattern of classroom characterized as a cultural script sustaining the teacher's decisions. This cultural pattern holds over the time and is widely shared (Givvin, Hiebert, Jacobs, Hollingsworth, \& Gallimore, 2005; Stigler \& Hiebert, 1999). Chile is not an exception: it seems there is a way of perceiving the process of teaching and learning mathematics where pen and paper are the main resource and students have a rather passive attitude, with no space 
for questions and interaction between them depending on the content of the study (Araya \& Dartnell, 2009; Preiss, Larraín, y Valenzuela, 2011; Radovic \& Preiss, 2010). Besides, "a conception of mathematics as a set of knowledge locked in themselves" is observed in the Primary Education classrooms (Espinoza, Barbé, \& Gálvez, 2011, p.122), affecting the way in which students relate mathematics to other areas of human knowledge.

International assessments, like the Program for International Student Assessment (PISA) and aforementioned TIMSS, have shown that teaching practices are not responding to the need for students to develop essential knowledge and skills related to mathematics in order to participate in modern societies (Agencia de Calidad de la Educación, 2014, 2017; OECD, 2014, 2016). Between 2014 and 2017, outcomes of Chilean Measurement System of Quality in Education (SIMCE) show that near 70\% of students are at an insufficient or elementary level regarding the standards in mathematics of the Chilean curriculum (Agencia de Calidad de la Educación, 2018).

This same assessment gathers data associated to students' personal and social development, relating it to academic achievement. Almost $50 \%$ of fourth grade students show low academic self-esteem and school motivation; also, they believe that academic skills cannot be improved. This percentage is closer to $60 \%$ in higher grades (Agencia de Calidad de la Educación, 2018).

Another fundamental variable in the teaching and learning processes is emotion, since emotions affect the performance of students (Pekrun \& Linnenbink-Garcia, 2012). The design of any didactic media to support learning should take the learner's emotions into account. However, very little was known about role and phenomenology of emotions in processes developed in different learning environments, most notably in learning supported by current technologies and multimedia tools used in our society (Pekrun, 2005).

The purpose of this study has been to create and evaluate a new software for the learning of fractions by using sound and music as a metaphor. In order to do this, this exploratory study was developed by means of three stages, namely: 1) generating significant music and sound metaphors relating to fractions and their representations; 2) developing the software and a didactic guide for teachers; and 3) assessment of software based on the students' perceptions taking a traditional approach that gather students' perception about their learning and a different one by means of a methodological apparatus called "balance of emotions" that allows for the evaluation of the emotional dimension with a simple but informative instrument regarding the emotional phenomenology provoked by using the educational software.

\section{Literature review}

\section{Learning music and learning mathematics}

With the focus aimed to music-mathematical activities, we seek to add a new sensorial experience to the mathematical class: the sound. Without sound, some integrated activities are only a symbolic manipulation absent of musical meaning. Conde (2011) reports this phenomenon in analyzing an activity from a sixth-grade scholar text in Mexico devoted to learning fractions with musical rhythm representations (note values). According to the author, the concept of fractions involves the division of the whole in equal parts, which is not possible to perceive if students only manipulate music symbols, sound representations. "In which manner may a semibreve [or whole note] be divided in equal parts to convert it into crotchets [or quarter note]?" The division in equal parts should be made with the sound itself, not by means of music symbols. Without sound, students have no opportunities to reflect on the notion 
of relative unit, which is necessary in conceptualizing fractions (Conde, Parada, \& Liern, 2016; Courey, Balogh, Siker, \& Paik, 2012; Kalinec-Craig, 2015; Liern, 2011).

Responding to this question, Conde, Figueras, Pluvinage and Liern (2011) report a computerized interdisciplinary environment for the study of fractions, the rhythm values and sound as physical phenomenon addressed to Primary School students. By using software, they incorporated sound to the rhythm values, along with representing by a bar the fraction corresponding to the duration of a sound. In the pilot study with sixth grade students from a public Primary school in Mexico City, authors mention that the use of different representations of fractions enabled students to establish order relationship between fractions, to express one fraction in terms of others and to discuss on the measure unit, infrequent topic in the study of fractions. Authors conclude that teachers require flexible resources that can be adjusted to the needs of their students, offering different approaches and representations on this kind of activities.

An (2012) proposes a model for the design of activities integrating mathematics and music. The model is organized in five phases, which are differentiated by its levels of focus in each of these areas. The first phase starts with an exclusively musical activity, in which the students create a musical product. The following phases involve mathematical questions associated with the musical product obtained. In the last phase, the focus is on mathematical contents, and elements of mathematical notation and formality are introduced. An important factor of this model is that all the activity is made from the same musical productions of the students, which are shared among the classmates.

An and her collaborators have carried out several quasi-experimental studies in form of prepost test control group designs. Their results show an effective use of different visual representations, such as drawings, tables and graphs, in conjunction with symbolic mathematical representations for solving problems by the experimental group over the control group (An, Capraro, \& Tillman, 2013; An \& Tillman, 2015). The researchers also found a positive improvement in students' attitudes and beliefs about mathematics and their own learning, which directly influences commitment to their own learning and decreases levels of anxiety towards mathematics (An, Kulm, \& Ma, 2008; An, Tillman, Boren, \& Wang, 2014).

A major project is the "European Music Portfolio: Sounding Ways into Mathematics" (EMPM) carried out by seven European countries between 2013 and 2016. The objective of this project was to gather successful classroom experiences in which mathematical and musical knowledge are integrated from a more holistic perspective, therefore favouring the learning of both disciplines (Casals, Carrillo, \& González-Martín, 2014). The experience, along with the associated resources, were made available through a virtual platform where teachers from all over the world, and from any level, may access the materials and guides for their application in the classroom.

Teachers have a fundamental role to carry out this kind of activity. Although teachers may be well valued, they are not recurrent in the classroom. For example, Chao, Mato and López (2015) applied a questionnaire to 360 primary education teachers and music education teachers of public schools in the province of Coruña, Spain. Although, these professors value both subjects as equally important for an integral development in their students, they do not feel qualified to design or implement an interdisciplinary activity. Still \& Bobis (2005) designed a large study to explore the knowledge, beliefs and practices of Primary school teachers in Sydney, Australia. The authors concluded that the teacher's decision to apply a music and 
mathematics activity depends on their belief that such approach would assist students build a deeper understanding of the concepts learnt.

In summary, the research reported here points to the characteristics of resources and musicmathematical activities that have a positive effect on the development of mathematical skills and knowledge, through challenging activities that promote positive changes in the attitude of students towards mathematical learning. Sound exploration and students musical production are key elements for this approach. The experience of EMP-M highlights that, in pre-service teacher training, both disciplines are equally important, and both provide an opportunity to learn mathematics and music. The role of the teacher cannot be left out of this reflection: decisions are mediated by both disciplinary knowledge and belief in the effectiveness of the activities.

\section{Teaching and learning fractions}

Regarding the teaching and learning of fractions, research documents the difficulty that students face in order to appropriate the notion of fractions and its use in early years, which will later affect their study of the rational number set. As an example, a research conducted in London in the 80's identified that students between 11 and 16 years of age presented confusion regarding the concept of fractions (Davis, Hunting, \& Pearn 1993). Replicating this study 20 years later, researchers discovered that the situation had not changed (Bills, 2003). In a study of over 400 students of first primary year in Argentina, it was determined that more than half of them are stuck in the natural numbers model, and therefore there is no appropriation of the concept of fraction and its operations (Pruzzo, 2012). The Delaware Longitudinal Study of Fraction Learning reports the development of fraction concepts and procedures by $3^{\text {th }}$ to $6^{\text {th }}$ grades students from United States (Hansen, Jordan, \& Rodrigues, 2017). The main results of this study point to the fact that the majority of students that begun with low achievement of the concept of fraction maintain low outcomes along that time period. In addition, they have difficulty learning more advanced mathematical content, a situation that is aggravated rather than improved in the higher degrees of instruction. The same is evidenced by another study (Siegler et al., 2012), which analysed large longitudinal data sets from the United States and the United Kingdom. The study concluded "that elementary school students' knowledge of fractions and whole-number division predicts their mathematics achievement in high school" over other factors considered in the study (p. 695).

In Chile, Olfos \& Guzmán (2011) carried out a study on 43 schools with different socioeconomic levels (SEL) in three cities of the Central Coast. The objective was to relate fourth grade students' knowledge with teacher' pedagogical knowledge on the concept, representations and procedures related to fractions. Results revealed that pupils presented difficulties and misunderstandings on the concept of fraction, which remained invariable between the different grades, no matter their SEL, even pupils with high SEL obtained better results than pupils with low SEL. Results also revealed that a vast part of teachers seemed to ignore such difficulties and misunderstandings.

As we pointed out previously, the difficulty that fractions, and consequently rational numbers, present to students is well acknowledged. This same reason explains the number of studies and proposals that seek to improve the teaching and learning of fractions, from the very moment they are first introduced. Some of the orientations we may find in these works are: (1) presenting students with multiple situations in which fractions are used, considering the most commonly used fractions $(1 / 2,1 / 4,3 / 4$, etc.) as well as contexts which are familiar to students (MINEDUC 2012); (2) the use of concrete material for fraction representation and their 
operations, apart from pictorical representation (Santos \& Ferreira, 2011); (3) investing time in teaching fractions from all perspectives and possible interpretations (Cramer, Post, \& del Mas, 2002; Pruzzo, 2012); (4) Representing and estimating fractions as points in a number line, determined by the division of the unitary segment in equal parts (Wu, 2008; Jordan, Resnik, Rodrigues, Hansen, \& Dyson, 2016); (5) understanding of fractions and decimal magnitudes, because it is necessary for students to make sense of the effects that arithmetical operations have on those magnitudes (Lortie-Forgues, Tian, \& Siegler, 2015). We may say that all these propositions aim at the need to worry about a deep conceptual knowledge about fractions and the comprehension of the information it offers us (Fazio \& Siegler, 2013).

The general recommendation is that instead of focusing on the presentation of a series of algorithms for the addition and multiplication of fractions and on rules for comparing fractions, it is better to center on its conceptual development. We should allow students to explore the functions of the numerator and denominator, provide them with mental images that allow them, later on, to comprehend that this mathematical symbol is actually a rational number.

\section{Cognition, embodied knowledge and emotions}

In addition to the interest and motivation aroused in students by the aforementioned musicmathematical relationship, we seek a software that appeals for embodied cognition. Sustained in neuroscientific evidence and in studies of cognitive linguistics referring to the nature of concepts, Gallese and Lakoff (2005) argue that conceptual knowledge is embodied. In other words, the sensory-motor system, those regions of the cortex responsible for integrating the information of the motor system with sensory information, such as visual, auditory, tactile information, among others, has the necessary structure to characterize the semantic content of the concepts and does so from the way in which the body of the individual interacts with the world. In terms of brain activity, imagination and doing something use the same neuronal substrate. The authors declare that to understand is to imagine, that both cognitive actions use the same neuronal substrate. The ability to imagine, and therefore to understand, is embodied, that is, is constantly restructured from each encounter or interaction with the world through the body and the brain (Gallese \& Lakoff, 2005; Tanaka, 2011).

Consistent with these conclusions, Radford and André (2009) develop the notion of the multimodal nature of cognition. These authors defend the need for a teaching of mathematics that does not depend mainly on language and signs, but where mutual collaboration between the different senses is recognized, since this allows a deep characterization of the semantic content of the concepts and processes of abstraction. In this way, the authors recommend the development of "school activities that request varied sensory modalities and allow, in turn, to integrate these activities into others of a more and more abstract nature" (p.221).

In general, human cognition can only be understood as a multimodal sensorial form culturally and historically constituted, which responds, acts, feels, transforms and gives meaning to the world creatively (Radford, 2014, p.349). The conception of cognition cannot appeal only to the domain of the "mental", away from the actions and experiences with the environment. On the contrary, thinking, reflecting, imagining, conjecturing, arguing and any superior cognitive ability is interconnected with the material and cultural aspects present in the world and, therefore, by the sensory capacities of the human body (Radford, 2014).

Affect is a construct that includes three other constructs: beliefs, attitudes and emotions. In this article, we used emotions in learning mathematics due to its relative importance in affect:

1) Emotions are in connection with people's goals (Hannula, 2006). 
2) Emotions are also seen to involve physiological reactions (Goleman, 1995).

3) Emotions are also seen to be functional, e.g., in human coping and adaptation (Goldin, 2000).

There is no consensus on how much basic emotions exist and what they are, but as emotions clearly affect cultural activities either beneficially or adversely, the important factor for this study is not the strict classification of an object as an emotion, a feeling or an affective state, but whether the 'emotion' stimulates or hampers the performance of tasks in learning situations. To date, little research has been done on the role of emotions with respect to computer related behaviours. Tangential research has focused extensively on computer anxiety, but other emotions such as anger, happiness, and sadness have been largely overlooked. The idea of using the emotional dimension as a criterion of quality of this software arose from the fact that little evidence is needed to demonstrate the presence of emotions in the learning process, as all people experience emotions when participating in education.

Some researchers uphold the role of emotions in educational processes supported by ICT, noting that certain proposals investigate and evaluate resources, strategies and activities aimed at the emotional regulation of educational processes and its analysis in online educational communication (Aires Teixeira, Azevedo, Gaspar, \& Silva, 2006). These studies affirm the importance of incorporating the analysis of the emotional dimension and the affective domain in the production of multimedia as educational material.

The purpose of this study was to develop software for learning fractions using music and sound as a metaphor. Also, to evaluate the software in base of the students' perceptions, including the emotions felt by students while working with the program. This emotional assessment could possibly confirm earlier evaluations from a more traditional perspective obtained from students after experimentation with AF.

\section{Method}

\section{Design and implementation of AudioFractions}

In order to implement the software object of this exploratory study, a framework was designed that allows the use of sound and music as working metaphors for mathematical concepts. An analysis of the most difficult math contents for the pupils at Primary Education was carried out in order to select the ones to include in the software (Thayer et al., 2012). The results enabled us to prioritize the mathematical concepts, such as representation, interpretation and operation with rational numbers, which are the subject of this study. This aforementioned framework is resumed next.

The design stage was carried out with help of experts on both mathematics and music education. Four brainstorming sessions were carried out, using an interdisciplinary approach, specifically seeking metaphors that would relate sound or music to mathematics, centered on the latter. Once filtered and classified, these ideas made up working models (nonfunctional prototypes). Each one of these models included a mathematical concept to develop and one sound-musical metaphor which could support the math concept.

After elaborating the design guide for the models and implementing the software by means of iterative prototyping, four of the models were developed on the software platform Pure Data (version 0.42.5; Puckette, 1996), one of them being AudioFractions (AF). The main goal of AF was to facilitate the representation, interpretation and operation with fractions associating a graphic representation (bars) with the pitch of sound. These representations were created from 
the idea of the pan flute, which consists of representing several tubes of different length, each one producing a tone of different pitch. The blue color of the bars represents the length (Figure 1). Students can modify the numerator by changing the blue part of the bar, so changing the length of the represented tube. In this manner, the selected fraction of the tube creates a sound whose pitch is the multiplicative inverse of the pitch corresponding to the tube's whole length.

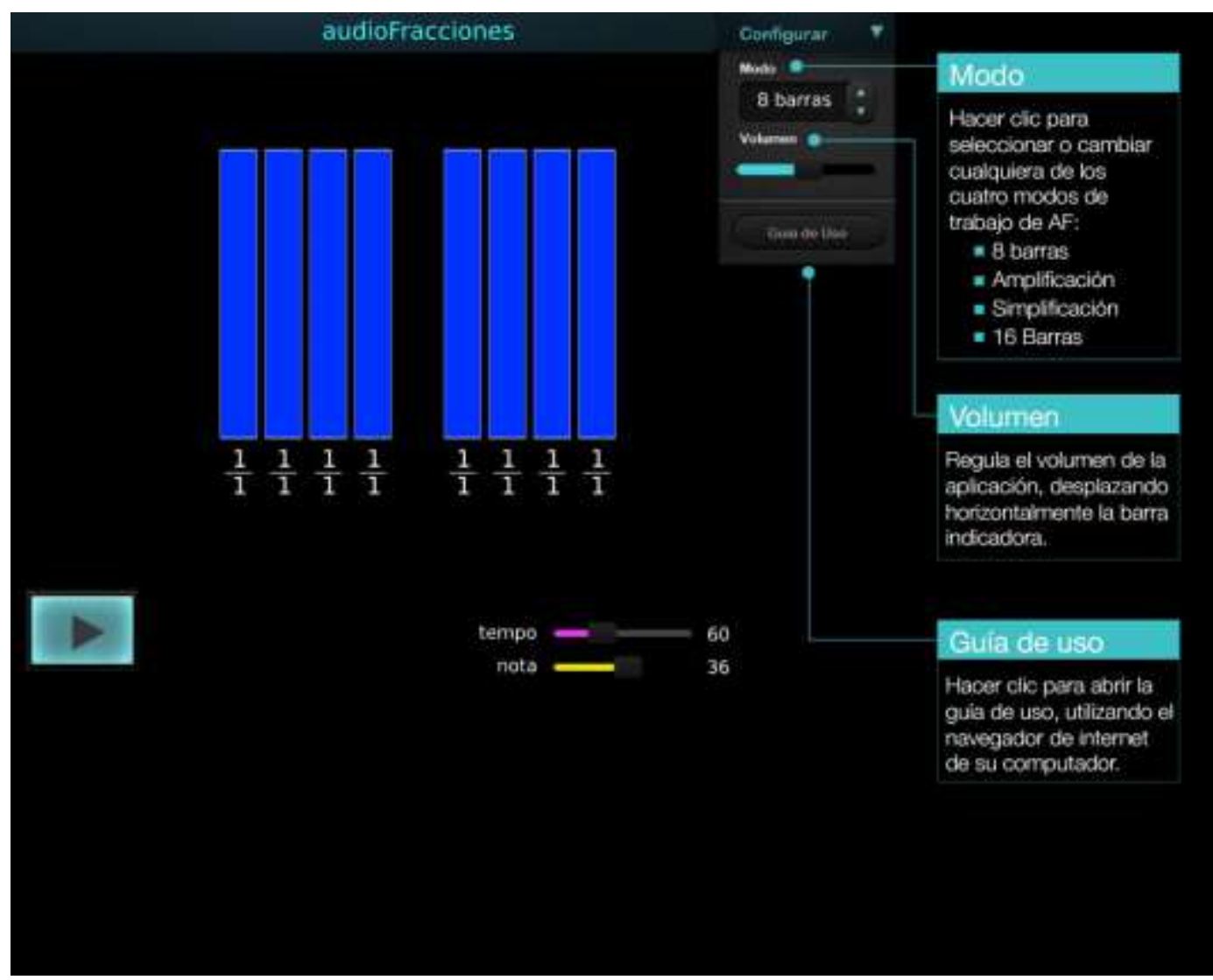

Figure 1: AudioFractions' eight-bars mode. The set of eight vertical bars can be freely manipulated in order to generate sounds shaping melodies with or without rhythm in eight steps. The numerator and denominator can be modified in a range of 1-16 (denominator) and 0-16 (numerator).

\section{Representation of fractions in AudioFractions}

AF proposes the interactive study of positive fractions that are less than one by means of an audiovisual representation, thus facilitating the association between representation (graphic bars), musical sounds (conceptual support) and the related mathematical concepts (fractions, operations, equivalences). The base element of the resource is the vertical bar representing the integer, which can be divided in up to 16 equal parts (denominator) in order to select before a certain number of that parts (numerator). AF introduces in a non-explicit way the notion of fraction as an expression that represents the part-of-a-whole.

From a musical perspective, the integer is represented in the software by one blue bar that corresponds to the root sound that one air column can generate. Higher pitches are produced when pupils reduce the numerator, that is, clicking a smaller amount of the bar's blue segments. Graphically, the construction of a musical sound is given first by the number of parts in which the denominator divides the bar, and second by the number of selected parts expressed by the numerator. AF has four modes of music-mathematical activities, which are based in the division of blue bars (root sound) in equal parts (Figures 1, 2 and 3). 


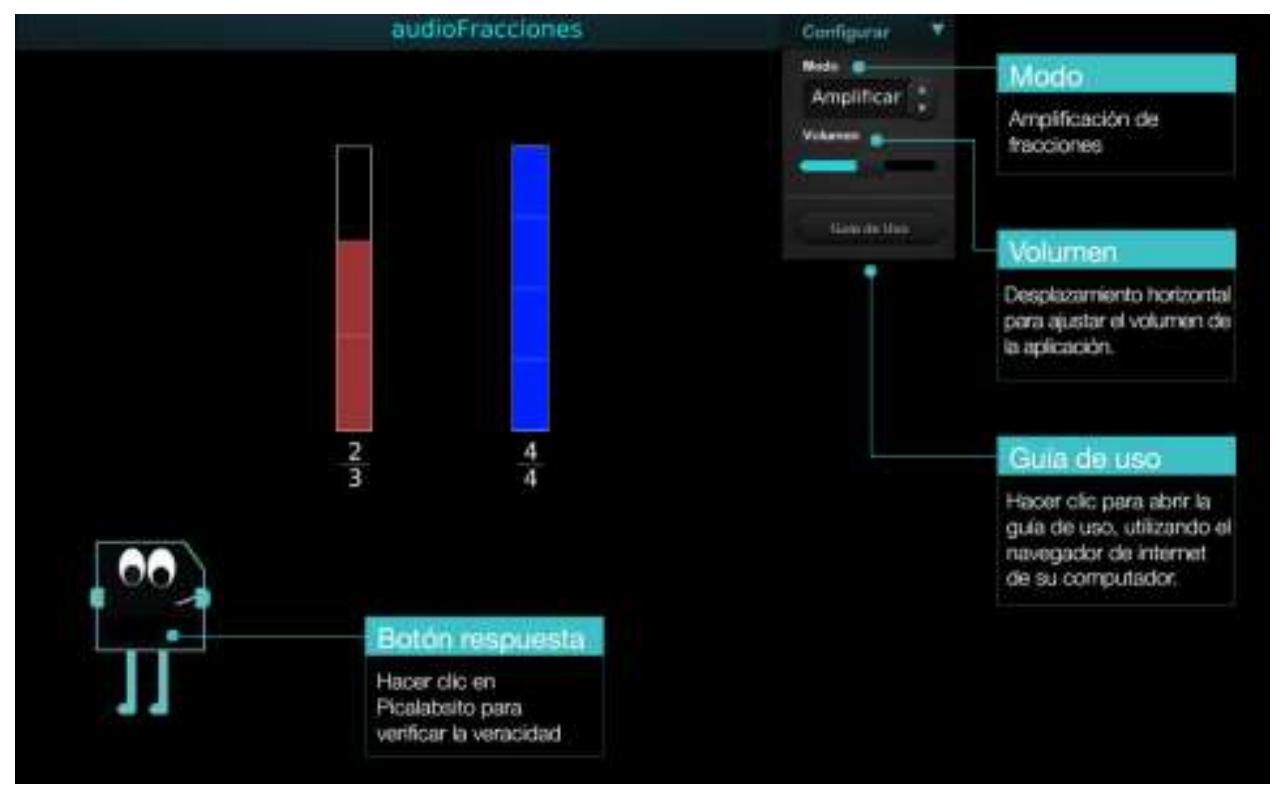

Figure 2: Amplification mode. In this mode, students work with the concept of equivalent fraction (amplification of fractions). Exercises are organized in three levels of difficulty. Students must figure out the fraction that produces the same sound as the given fraction. Mathematically, it means the student must determine a set of equivalent fractions using amplification procedures (multiplication).

The activities of Simplification Mode have three levels of difficulty. Students must find out one, two or three sound fractions equivalent to a given one by means of simplification procedures (division).

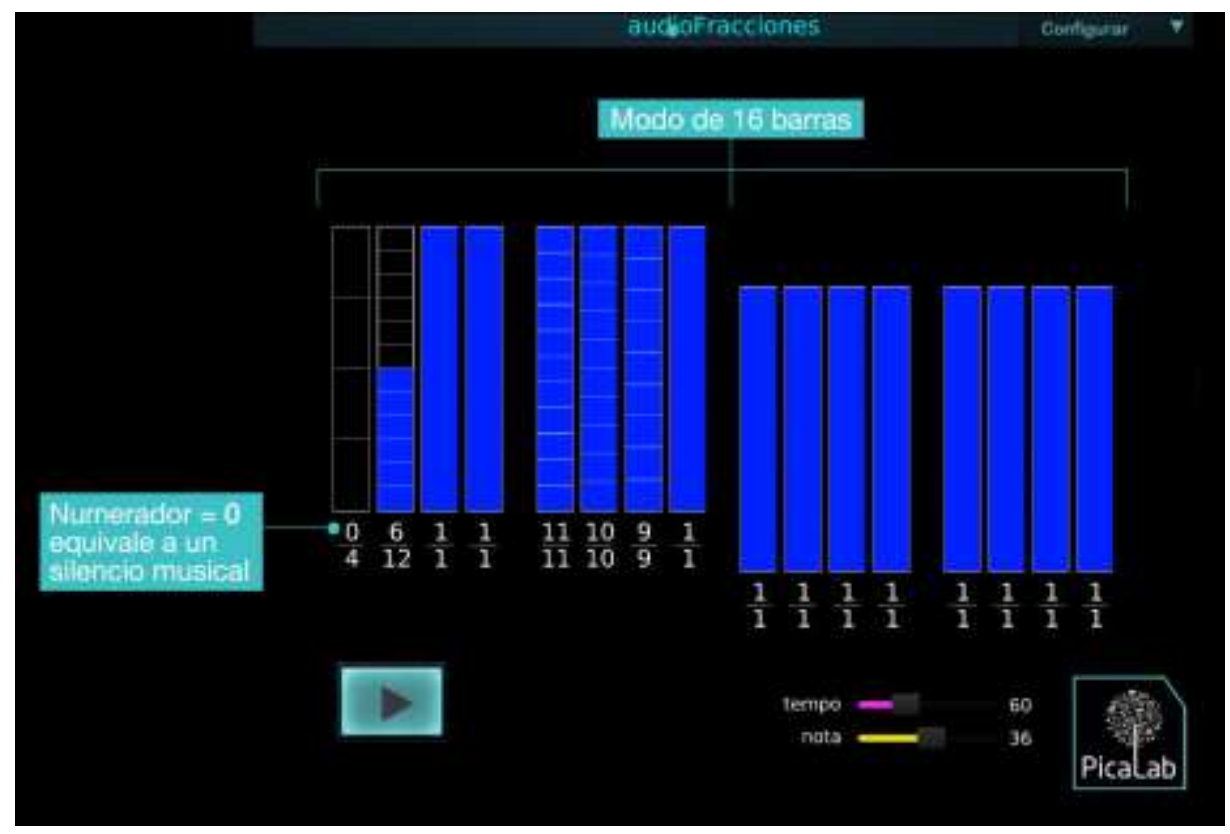

Figure 3: AudioFractions' sixteen-bars mode. This mode is similar to eight-bars mode. In it, students can freely manipulate a set of sixteen bars in order to generate melodic sequences (with or without rhythm). Numerator zero is equal to a bar-length silence. 


\section{Evaluation}

The third stage consisted in the evaluation of AF by Primary Education students at Priority Schools (schools with children in risk of social exclusion) in Santiago's Metropolitan Area (Chile). For the evaluation of the software in which people intervened, permission was requested from the Ethical Commission of the University, which was granted.

\section{a) Pilot study}

Previous to the software evaluation, a pilot study was carried out in a priority school of Santiago $(n=40 ; 8-13$ years old). This pilot was used to refine the assessment protocol as well as the data gathering instrument for the four computer programs included AF.

\section{b) Sample}

The population for the evaluation stage was selected by means of probabilistic sampling among children of Priority Primary Schools of Peñalolen (Santiago's Metropolitan Area) (n=137 aged 8-11). Three priority schools were selected between the priority schools in Santiago's Metropolitan Area (schools A, B and C; Table 1) taken as criteria the lower marks obtained by students using a method for learning mathematics called Compumat implemented by Local Education Board.

Table 1: Sample of this study, characterized by school, course and gender.

\begin{tabular}{|l|l|}
\hline $\begin{array}{l}\text { Sample } \\
\text { per school }\end{array}$ & $\mathbf{N}$ \\
\hline $\mathrm{A}$ & $\begin{array}{l}25 \\
(18 \%)\end{array}$ \\
\hline $\mathrm{B}$ & $\begin{array}{l}25 \\
(18 \%)\end{array}$ \\
\hline $\mathrm{C}$ & $\begin{array}{l}87 \\
(64 \%)\end{array}$ \\
\hline
\end{tabular}

\begin{tabular}{|l|l|}
\hline $\begin{array}{l}\text { Sample } \\
\text { per course }\end{array}$ & $\mathbf{N}$ \\
\hline 3th. course & $\begin{array}{l}30 \\
(22 \%)\end{array}$ \\
\hline 4th. course & $\begin{array}{l}63 \\
(46 \%)\end{array}$ \\
\hline 5th. course & $\begin{array}{l}44 \\
(32 \%)\end{array}$ \\
\hline
\end{tabular}

\begin{tabular}{|l|l|}
\hline $\begin{array}{l}\text { Sample } \\
\text { per gender }\end{array}$ & $\mathbf{N}$ \\
\hline Female & $\begin{array}{l}72 \\
(52 \%)\end{array}$ \\
\hline Male & $\begin{array}{l}65 \\
(48 \%)\end{array}$ \\
\hline
\end{tabular}

\section{c) Control of variables}

In order to determine and verify the influence of potential variables on the students' evaluation, several items were included in the data gathering instrument (see below):

1) gender, 2) previous musical experiences (participation in non-school music activities), 3) previous mathematical knowledge (participation in extra-academic mathematical activities), 4) self-perception of mathematical competency, 5) self-perception of musical competency, 6) mathematical achievement (previous year's qualification); 7) music achievement (previous year's qualification), 8) self-perception of abilities related to the use of computers, 9) frequency of use of computers, 10) type of use of the computer.

\section{d) Data gathering instrument}

A questionnaire was designed in order to collect data. Assessment questionnaire items were expressed as affirmative sentences which were to be responded using a Likert type scale, that is frequently used in the domain of education to gather data relative to participants' perceptions. Since participants were children, each point of the scale was represented by one icon (a face), enabling pupils to express their opinions about AF by establishing a level of agreement to the sentence.

In the first part of the questionnaire, data on potential intervenient variables (see above) was collected in order to analyze its influence as covariable of the assessment results. The questionnaire included a number of items grouped in four measurement scales: 
1) Mathematical learning (items 15 to 22; Table 3), defined as the perceived potentiality of mathematical learning using the program (easiness, understanding maths, fun, preference to use the software).

2) Music and sound learning (items 23 to 26; Table 4), defined as the perceived potentiality of music and sound learning using the program (easiness, understanding music, fun and preference to use the software).

3) Technical assessment (items 38 to 42; Table 5), defined as the perceived quality of the program evaluated based on stability, comprehension of software's graphical interface and instructions, easiness and preference to use the software.

4) Global assessment (items 28 to 31 ; Table 2).

We should mention here that data collected are the agreement or disagreement in respect to a statement. The items included in each of these measurement scales are show in tables at Results section.

Additionally, an affective-emotional dimension was included as a control list with 7 positive emotions and 7 negative ones (unpaired items). Students had to mark the ones that represented the way they felt while working with AF (item no. 36). Students who did not relate to any emotion from the list, should not mark anything. In data analysis, this affective-emotional dimension was correlated with the remaining assessment dimensions of AF.

Three open items were included in order to know: 1) what mathematical elements were learnt by pupils (item 33); 2) the elements they liked the most (item 34); and 3) the elements they did not like (item 35). Data associated with these items are not shown here.

The questionnaire was validated by two judges, experts on the fields of mathematical education and music education $(\mathrm{k}=0.952)$. The validation was based on the experts' scores (dichotomic responses) on the adequacy and relevance of each item.

\section{e) Materials}

For the evaluation, the following resources were used:

- PC computers with Windows operative system running several hardware configurations in the computer lab of the schools were the evaluation was carried out.

- AudioFractions software

- Questionnaire

\section{f) Procedure}

One sixty-minute training session was carried out in order to expose the students to the software. Each student was working with one computer. The controllers (activity monitors) provided fast and clear instructions about mathematical contents and use of AF. After this, students put on earphones and began the first activity, which was guided by a question of the AF's didactic guide along the line of the Theory of Didactic Situations (Brousseau, 1998). Once finished with this activity, they continued with the next one and so on. After this training session, the assessment questionnaire was delivered. The controllers solved any problem or questions students might have while working with AF (mathematics, use of software, music, and questionnaire). All these issues were reported to the researchers in an ad hoc file. 


\section{Results}

Evaluation data was processed using IBM SPSS software, with a confidence level of $95 \%$. No significant correlations were found between the potential variables of influence aforementioned and the items of evaluation.

\section{a) Global assessment}

Students' perceptions on AudioFractions' global assessment was determined by the items 27 to 31 of the questionnaire, which asked the level of agreement with a statement by means of a five-point-scale. The results show biased positive scores and a discrete dispersion of them. The evaluation of students $(\mathrm{N}=137)$ shows very high values, which could be interpreted as they positively perceive AF for the learning of mathematics (Table 2).

Table 2: Students' perceptions of AudioFractions. Global assessment items.

\begin{tabular}{|l|l|l|}
\hline Item & $M$ & SD \\
\hline 27. I could participate in math class if I used this kind of software & 4.16 & 1.429 \\
\hline 28. I liked the teacher taught me this software & 4.29 & 1.351 \\
\hline 29. I have understood much better math exercises using this software & 4.00 & 1.518 \\
\hline 30. I liked to use this software at home & 4.08 & 1.459 \\
\hline 31. Teacher resolved my doubts while working with the software & 4.11 & 1.513 \\
\hline
\end{tabular}

\section{b) Assessment of mathematical learning}

Students' perceptions on mathematical learning with AF was determined by the items 15 to 22 of the questionnaire in the same way as the aforementioned dimension. The results show high positive scores and a discrete dispersion (Table 3).

\section{Table 3: Students' perceptions of mathematical learning using AudioFractions.}

\begin{tabular}{|l|l|l|}
\hline Item & $\boldsymbol{M}$ & SD \\
\hline 15. Mathematical activities with this software are fun. & 4.33 & 1.038 \\
\hline 16. This software have taught me things I did not know before. & 4.20 & 1.268 \\
\hline 17. I would like learn Mathematics with this software & 4.13 & 1.407 \\
\hline 18. I would like to use this software in math classes. & 4.37 & 1.156 \\
\hline 19. I understood very well the actions I had to do. & 4.07 & 1.360 \\
\hline 20. Mathematical activities proposed by the software are easy. & 4.03 & 1.319 \\
\hline 21. This software helped me to understand better math exercises. & 4.25 & 1.275 \\
\hline 22. I want to follow math classes with this software. & 4.35 & 1.288 \\
\hline
\end{tabular}


c) Assessment of music and sound learning

Items 23 to 26 of the questionnaire determined the music-learning assessment dimension of AF. The results show high positive scores and a discrete dispersion (Table 4).

Table 4. Students' perceptions of music and sound learning using AudioFractions

\begin{tabular}{|l|l|l|}
\hline Item no. & $\boldsymbol{M}$ & SD \\
\hline 23. This software helped me to understand better music and sound. & 4.36 & 1.134 \\
\hline 24. Sound and Music helped me to understand the math exercises. & 4.20 & 1.232 \\
\hline 25. Sound and Music activities are easy. & 4.15 & 1.275 \\
\hline 26. I liked to use music and sound to resolve math exercises. & 4.40 & 1.171 \\
\hline
\end{tabular}

\section{d) Technical assessment}

Students' perceptions about the technical aspects of AF was determined by the items 38 to 42 of the questionnaire. The results show very high positive scores and a discrete dispersion (Table 5). That could be interpreted as a high agreement with the statements of the scale, therefore with the technical quality of the software.

Table 5: Students' perceptions about AF's technical aspects.

\begin{tabular}{|l|l|l|}
\hline Item no. & $\boldsymbol{M}$ & SD \\
\hline 38. I have quickly understood the functions of the software & 4.01 & 1.682 \\
\hline 39. I have understood the software user's instructions. & 3.97 & 1.655 \\
\hline 40. Software has run well when I worked the activities. & 3.96 & 1.674 \\
\hline 41. I like the software's buttons and commands. & 3.93 & 1.624 \\
\hline 42. Software seems well arranged. & 4.15 & 1,646 \\
\hline
\end{tabular}

\section{e) Assessment of the affective-emotional domain}

As previously mentioned, emotional assessment (item no. 35) was based on a control list of 7 positive emotions and 7 negative emotions (unpaired, no semantic scale). Results show pupils felt more positive emotions than negative ones, which indicate a good evaluation of the affective-emotional domain (Figure 4), even though $15 \%$ of pupils did not answer this item.
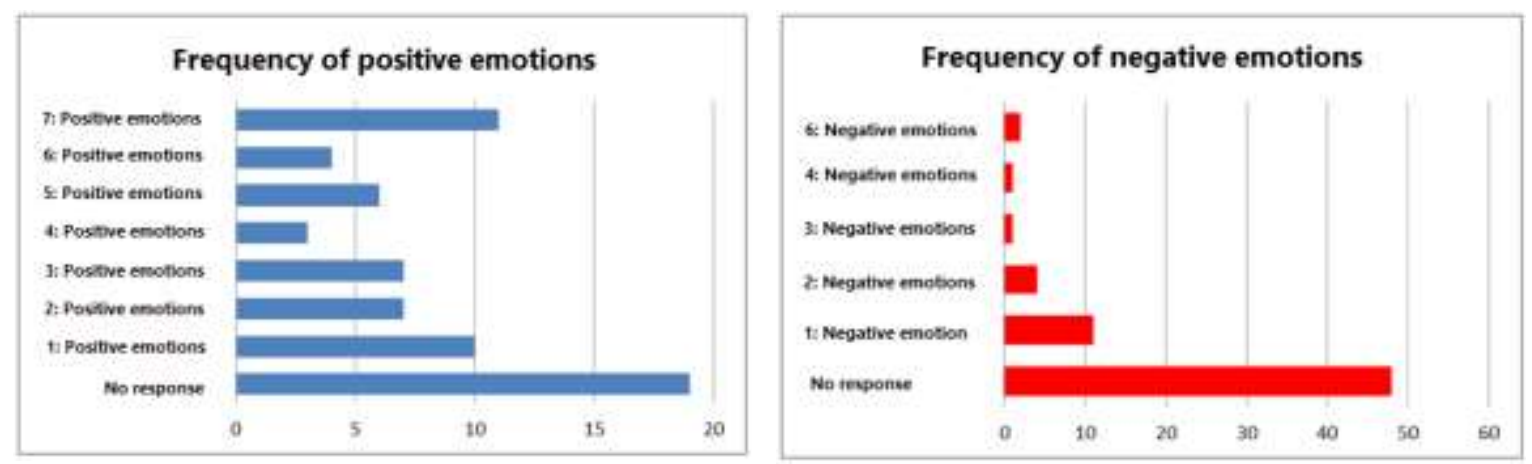

Figure 4: Frequency of positive and negative emotions perceived by pupils in the assessment of AudioFractions. Vertical axis represents the number of emotions felt by students. Horizontal axis represents the number of cases. 
According to the data obtained, some statistically significant direct correlations between positive emotions and global assessment at low degree of association can be observed (Table 6). As emotions increase, there is an increase in global assessment. In all other cases, it can be affirmed that there is a positive correlation, but a very low level of association.

Table 6: Correlations between positive emotions and the dimensions of assessment of AudioFractions.

\begin{tabular}{|l|r|r|}
\cline { 2 - 3 } \multicolumn{1}{c|}{} & \multicolumn{1}{|l|}{$\begin{array}{l}\text { Rho } \\
\text { Spearman }\end{array}$} & P value \\
\hline $\begin{array}{l}\text { Correlation positive emotions and } \\
\text { global assessment }\end{array}$ & 0.261 & $\mathbf{0 . 0 0 2} *$ \\
\hline $\begin{array}{l}\text { Correlation positive emotions and } \\
\text { mathematical learning }\end{array}$ & 0.174 & $\mathbf{0 . 0 4 2 *}$ \\
\hline $\begin{array}{l}\text { Correlation positive emotions and } \\
\text { music learning }\end{array}$ & 0.180 & $\mathbf{0 . 0 3 5} *$ \\
\hline $\begin{array}{l}\text { Correlation positive emotions and } \\
\text { technical assessment }\end{array}$ & 0.193 & $\mathbf{0 . 0 2 4} *$ \\
\hline
\end{tabular}

Also, data shows some statistically significant inverse correlations at medium and low level of association (Table 7) between negative emotions and global assessment at an association level considered very low. As the negative emotions increase, there is a decrease in the overall assessment. In all other cases, it can be affirmed that there is a positive correlation, but a very low level of association. These results on positive and negative emotions in working with computer programs are consistent with other findings (Tejada, Pérez-Gil \& Pérez, 2011).

Table 7: Correlations between negative emotions and the dimensions of assessment of AudioFractions.

\begin{tabular}{|l|r|r|}
\cline { 2 - 3 } \multicolumn{1}{c|}{} & $\begin{array}{l}\text { Rho } \\
\text { Spearman }\end{array}$ & P value \\
\hline $\begin{array}{l}\text { Correlation between negative } \\
\text { emotions and global assessment }\end{array}$ & -0.167 & 0.051 \\
\hline $\begin{array}{l}\text { Correlation between negative } \\
\text { emotions and mathematical } \\
\text { learning }\end{array}$ & -0.199 & $\mathbf{0 . 0 2 0} *$ \\
\hline $\begin{array}{l}\text { Correlation between negative } \\
\text { emotions and music learning }\end{array}$ & -0.247 & $\mathbf{0 . 0 0 4} *$ \\
\hline $\begin{array}{l}\text { Correlation between negative } \\
\text { emotions and technical assessment }\end{array}$ & -0.097 & 0.258 \\
\hline
\end{tabular}

Finally, reports from controllers gave extra perception about students' attitudes towards AF. Basically, all of them were positive. Students showed motivation to: 1) use the program; 2) solve the controllers' questions. These reports describe a distended context in which students asked for questions related with mathematics and sound and music, and particularly questions which showed greater insight into both the musical and mathematical concepts than those that arise in "normal" math classes. Questions regarding use of the program were barely asked to controllers. It follows that the interface was robust, functional and simple enough to be used by this kind of students. 


\section{Conclusions}

It may be concluded that students from third and fifth grade of Primary Education in Chile considered it a positive experience to learn rational numbers through the use of sound and music by using AF software. The data collected shows a good disposition towards the program: all evaluated dimensions - mathematical learning, musical learning, global, technical, affective/emotional- show high scores.

It has been difficult to do some contrasts with similar studies because of the singularity of this work. First of all, the purposes and functions of the software created are unique at the present scenario. Secondly, it has been difficult to carry out a study of effectivity because of the restrictions of math teachers, who did not consent to work with this software. Likely, math teachers in Chile are pretty much stressed by the accomplishment of math curriculum goals because of the pressure of national assessment, namely SIMCE, which is the national evaluation for the achievement in Primary and Secondary schools. So, the assessment was made by students in another class. No collaboration was obtained from the math teachers. Likely, the high scores given by pupils may be due to the fact of using the software in a regular math class which represented a change in their daily routines.

Clarke, Keitel \& Yoshinori (2006) consider that a good practice "is a culturally-determined entity". So, analysing practices of other countries have nothing to do with searching "the 'ideal' mathematical classroom" but contributing to the reflection on "our own assumptions about our own practice" for continuously enhancing them (p. 11). By means of this study, we want to be part of this reflection and the results observed with Chilean students could contribute to reflection in other countries. We propose an interdisciplinary music-mathematical learning resource, which appeals for embodied cognition and multimodality of concepts (Gallese \& Lakoff, 2005; Radford \& André, 2009; Radford, 2014), where sensory and motor experiences are as much or more relevant than language and signs in mathematical activity. The importance of sound and music, then, do not consist only in finding contexts that are close to or of interest to students, but to diversify both sensory and emotional experiences in the classroom.

The high scores on the perceptions on mathematical and musical learning and affective/emotional dimensions constitute, de facto, a triangulation of data, a convergent validity: it is logical to think that there is a correlation between the value given by the student to a didactic mediator for learning of a certain subject -in this case, the AudioFractions software -and the positive emotions felt during its use. The program has provided a varied emotional experience, comprised to a learning process. The necessary actions for learning pick up the incidence of negative emotions typical to a process of effort and uncertainty when faced to a process of learning with a new tool. Therefore, the presence of negative emotions such as stress, tiredness, worry or anger is normal and expected. Nevertheless, positive emotions are much more widely present.

These results allow us to conclude that AudioFractions generate a greater level of emotional satisfaction, which can be observed both in the distribution of the areas of these variables and in the correlation with other dimensions of the evaluation. This produces a very positive vision of the emotional and regulatory processes developed. The incorporation of an affective/emotional analysis, as criteria for evaluation, seems pertinent and complementary to other criteria in the production of multimedia material with educational purposes both in formal and non-formal domains of education. This software gives teachers an important tool to tackle difficult concepts, such as fractions, with a better disposition by students, giving them greater 
chances of success in the teaching/learning process. Future study should be carried out to measure effective learning impact of the use of such tools and the application of more structured instruments to gather data related to emotions

\section{Acknowledgments}

This research has been funded by: 1) Fondo para la Promoción del Desarrollo Técnico y Científico (FONDEF) dependent on CONICYT (Government of Chile, TIC-EDU TE10I010), 2) Programa de Atracción de Capital Humano Avanzado Extranjero (CONICYT, Folio: PAI80160102) and 3) Beca de Doctorado Nacional 2015 from the Programa de Formación de Capital Humano Avanzado, CONICYT, Government of Chile (Folio: 21151503). The authors declare that they have no conflict of interest and that the funds aforementioned are complementary.

\section{References}

Agencia de Calidad de la Educación. (2014). Informe Nacional Resultados Chile PISA 2012 [National Results Report Chile PISA 2012]. Retrieved from: http://archivos.agenciaeducacion.cl/Informe_Nacional_Resultados_Chile_PISA_2012.pdf

Agencia de Calidad de la Educación. (2017). Informe Nacional TIMSS 2015 [National Results Report TIMSS 2015]. Retrieved from: http://archivos.agenciaeducacion.cl/TIMSS_V03_27MAR.pdf

Agencia de Calidad de la Educación. (2018). Resultados Educativos 2017 [Simce 2017 press conference presentation]. Retrieved from: http://www.agenciaeducacion.cl/evaluaciones/que-es-el-simce/

Aires, L., Teixeira, A., Azevedo, J., Gaspar, M., \& Silva, S. (2006). Alteridad y emociones en las comunidades virtuales de aprendizaje. Revista electrónica Teoría de la Educación, 7(2), 74-91. Retrieved from: http://www.usal.es/ teoriaeducacion/rev_numero_07_02/n7_02_luisa_aires.pdf

An, S. (2012). The effects of music-mathematics integrated curriculum and instruction on elementary students mathematics achievement and dispositions. (Unpublished doctoral dissertation). A\&M University, Texas, TX, USA. Retrieved from http://search.proquest.com/docview/1035271302?accountid=14777

An, S., Caprano, M. M., \& Tillman, D. (2013). Elementary Teachers Integrate Music Activities into Regular Mathematics Lessons: Effects on Students' Mathematical Abilities. Journal for Learning through the Arts, 9(1), 1-19. Retrieved from: http://escholarship.org/uc/item/0js732gf

An, S. A., Kulm, G. O., \& Ma, T. (2008). The effects of a music composition activity on Chinese students' attitudes and beliefs towards mathematics: An exploratory study. Journal of Mathematics Education, 1(1), 91-108. Retrieved from: http://educationforatoz.com/images/ 8 Song_An_- music and math.pdf

An, S., \& Tillman, D. A. (2015). Music activities as a meaningful context for teaching elementary students mathematics: a quasi-experiment time series design with random assigned control group. European Journal of Science and Mathematics Education, 3(1), 45-60. Retrieved from: https://eric.ed.gov/?id=EJ1107839

An, S., Tillman, D., Boren, R., \& Wang, J. (2014). Fostering Elementary Students' Mathematics Disposition through Music-Mathematics Integrated Lessons. International Journal for Mathematics Teaching and Learning. Retrieved from: http://www.cimt.org.uk/journal/an.pdf

Araya, R., \& Dartnell, P. (2009). Saberes pedagógicos y conocimiento de la disciplina matemática en docentes de Educación General Básica y Media [Pedagogical knowledge and knowledge of the mathematical discipline in teachers of Primary and Secondary Education]. En Ministerio de Educación de Chile (Ed.), Selección de investigaciones Primer Concurso FONIDE: evidencias para políticas públicas en educación (pp. 157-198). Santiago, Chile: Departamento de Estudios y Desarrollo, Ministerio de Educación de Chile. Retrieved from: www.ciae.uchile.cl/download.php?file=publicaciones/S-1365016663.pdf

Bills, C. (2003). Errors and Misconceptions in KS3 'number'. In J. Williams (ed.), Proceedings of the British Society for Research into Learning Mathematics, 23(3), 7-12. Retrieved from: https://www.ucl.ac.uk/ioe/research/featured-research/upmap/pdf/BSRLM_IP 31_1_Full.pdf

Brousseau G. (1998). Théorie des Situations Didactiques. Grenoble: La Pensée Sauvage.

Casals, A., Carrillo, C., \& González-Martín, C. (2014). La música también cuenta:combinando matemáticas y música en el aula [Music also Matters: Combining Math and Music in the Classroom]. Revista Electrónica de Música en la Educación, 34, 1-17. Retrieved from: http://musica.rediris.es/leeme/revista/casalsetal14.pdf

Chao, R., Mato, M. D., \& López, A. M. (2015). ¿Se trabajan de forma interdisciplinar música y matemáticas en educación infantil? [Are music and mathematics interdisciplinary approached in early childhood education?]. Educação e Pesquisa, 41(4), 1009-1022. http://dx.doi.org/10.1590/S1517-9702201512139014

Clarke, D., Keitel, C., \& Shimizu, Y. (2006). The Learner's Perspective Study. In D. Clarke, C. Keitel \& Y. Shimizu (Eds.), Mathematics Classrooms in Twelve Countries: The insider's Perspective (pp. 1-14). Rotterdam: Sense Publishers. 
Conde, A. (2011). Un acercamiento a las fracciones por medio de la música: un problema de enseñanza y aprendizaje [An approach to fractions through music: a teaching and learning problem]. In P. Lestón (Ed.), Acta Latinoamericana de Matemática Educativa (pp. 419-427). México, DF: Comité Latinoamericano de Matemática Educativa. Retrieved from: http://funes.uniandes.edu.co/4834/

Conde, A. Parada, S., \& Liern, V. (2016). Estudio de Fracciones en Contextos sonoros [Study of fractions in sound contexts]. Actualidades Investigativas en Educación, 16(2), 1-21. http://dx.doi.org/10.15517/aie.v16i2.23933

Conde, L., Figueras O., Pluvinage, F., \& Liern, V. (2011). El sonido de las fracciones: Una propuesta interdisciplinaria de enseñanza (sounds of fractions: an interdisciplinary proposal of teaching). Suma, 68, 107-113.

Courey, S. J., Balogh, E., Siker, J. R., \& Paik, J. (2012). Academic music: music instruction to engage thirdgrade students in learning basic fraction concepts. Educational Studies in Mathematics, 81(2), 251-278. doi:10.1007/s10649-012-9395-9

Cramer, K. A, Post, T. R., \& del Mas, R. C. (2002). Initial Fraction Learning by Fourth- and Fifth-Grade Students: A Comparison of the Effects of Using Commercial Curricula With the Effects of Using the Rational Number Project Curriculum. Journal for Research in Mathematics Education, 33(2), 111-144.

Davis, G.E., Hunting, R.P., \& Pearn, C. (1993). What Might a Fraction Mean to a Child and How Would a Teacher Know? Journal of Mathematical Behavior, 12, 63-76.

Espinoza, L., Barbé, J., \& Gálvez, G. (2011). Limitaciones en el desarrollo de la actividad matemática en la escuela básica: el caso de la aritmética escolar [Limitations in the development of mathematical activity in basic school: the case of school arithmetic]. Estudios Pedagógicos, 37(1), 105 - 125. http://dx.doi.org/10.4067/S0718-07052011000100006.

Fazio, L., \& Siegler, R.S. (2013). Enseñanza de las Fracciones. Series Prácticas Educativas-22 [Teaching of the fractions. Practical series no. 22]. Quito, Ecuador: Mantis Comunicaciones. Retrieved from: http://unesdoc.unesco.org/images/0021/002127/212781S.pdf

Gallese, V., \& Lakoff, G. (2005). The brain's concepts: The role of the sensory-motor system in conceptual knowledge. Cognitive Neuropsychology, 22(3-4), 455-479. doi: 10.1080/02643290442000310

Givvin, K. B., Hiebert, J., Jacobs, J. K., Hollingsworth, H., \& Gallimore, R. (2005). Are there national patterns of teaching? Evidence from the TIMSS 1999 video study. Comparative Education Review, 49(3), 311-343. Retrieved from: https://www.timssvideo.com/sites/default/files/National\%20Patterns\%20of\%20Teaching.pdf

Goldin, G. A. (2000). Affective pathways and representation in mathematical problem solving. Mathematical Thinking and Learning, 2 (3), 209-219. doi:10.1207/S15327833MTL0203_3

Goleman, D. (1995). Emotional intelligence. New York: Bantam Book.

Hannula, M. S. (2006). Motivation in mathematics: Goals reflected in emotions. Educational Studies in Mathematics, 63(2), 165-178. Retrieved from: https://goo.gl/KoQwLy

Hansen, N., Jordan, N. C., \& Rodrigues, J. (2017). Identifying learning difficulties with fractions: A longitudinal study of student growth from third through sixth grade. Contemporary Educational Psychology, 50, 45-59. doi:10.1016/j.cedpsych.2015.11.002

Jordan, N. C., Resnick, I., Rodrigues, J., Hansen, N., \& Dyson, N. (2016). Delaware Longitudinal Study of Fraction Learning: Implications for Helping Children with Mathematics Difficulties. Journal of Learning Disabilities, 50(6), 621-630. doi:10.1177/0022219416662033

Kalinec-Craig, C. A. (2015). Uncovering the Mathematical Challenges and Connections When Using Mariachi Music as a Representation for Teaching Equivalent Fractions. Journal of Mathematics Education, 8(2), 320. Retrieved from: http://educationforatoz.com/images/2015_Crystal_Kalinec-Craig.pdf

Liern, V. (2011). Música y Matemáticas en Educación Primaria [Music and Mathematics in Primary Education]. Suma, 66, 107-112. Retrieved from: https://revistasuma.es/IMG/pdf/66/107-112.pdf

Lortie-Forgues, H., Tian, J., \& Siegler, R. S. (2015). Why is learning fraction and decimal arithmetic so difficult? Developmental Review, 38, 201-221. doi:10.1016/j.dr.2015.07.008

MINEDUC (2012). Matemática Bases curriculares 2012 [Mathematics: curricular bases]. Santiago, Chile: Unidad de Currículum y Evaluación, Ministerio de Educación. Retrieved from: http://www.curriculumnacional.cl

OECD (2014). PISA 2012 Results: What Students Know and Can Do - Student Performance in Mathematics, Reading and Science (volume I, revised edition) [Versión OECD Publishing]. doi:10.1787/9789264201118en

OECD (2016). PISA 2015 Results: Excellence and Equity in Education (Volume I). Paris: OECD Publishing. doi:/10.1787/9789264266490-en

Olfos, R., \& Guzmán, I. (2011). Dificultades en el aprendizaje de las fracciones y el conocimiento del profesor [Difficulties in the learning of fractions and the knowledge of the teacher]. XIII CIAEM-IACME Conference, Recife, Brasil. Retrieved from: https://ciaem- 
redumate.org/ocs/index.php/xiii_ciaem/xiii_ciaem/paper/view/2391/326

Pekrun, R. (2005). Emotions and Learning. Paris: UNESCO. Retrieved from: http://www.ibe.unesco.org

Pekrun, R., \& Linnenbink-Garcia, L. (2012). Academic emotions and student engagement. In S.L. Christenson, A.L. Reschly, \& C. Wylie (Eds.), Handbook of Research on Student Engagement (pp. 259-282). New York, NY: Springer.

Preiss, D., Larraín, A., \& Valenzuela, S. (2011). Discurso y pensamiento en el aula matemática chilena. Psykhe, 20(2), 131-146. doi: 10.4067/S0718-22282011000200011

Pruzzo, V. (2012). Las fracciones: problema de aprendizaje o problemas de la enseñanza [Fractions: learning problem or teaching problems] Revista Pilquen,14(8), 1-14.

Puckette, M. (1996). Pure Data v. 0.42.5 [Computer software]. Retrieved from: https://puredata.info/

Radford, L. (2014). Towards an embodied, cultural, and material conception of mathematics cognition. ZDM Mathematics Education, 46(3), 349-361.

Radford, L., \& André, M. (2009). Cerebro, cognición y matemáticas [Brain, cognition and Mathematics]. Revista Latinoamericana de Investigación en Matemática Educativa, 12(2), 215-250.

Radovic, D., \& Preiss, D. (2010). Patrones de Discurso Observados en el Aula de Matemática de Segundo Ciclo Básico en Chile [Patterns of Discourse Observed in the Classroom of Mathematics of the Second Basic Cycle in Chile]. PSYKHE, 19(2), 65-79. doi:10.4067/S0718-22282010000200007

Santos, V., \& Ferreira, J. (coords.) (2011). Números: linguagem universal [Numbers: universal language]. Rio de Janeiro, Brazil: Instituto de Matemática, Universidade Federal do Rio de Janeiro.

Siegler, R. S., Duncan, G. J., Davis-Kean, P. E., Duckworth, K., Claessens, A., Engel, M., Susperreguy, M. I., \& Chen, M. (2012). Early Predictors of High School Mathematics Achievement. Psychological Science, 23(7), 691-697. doi: 10.1177/0956797612440101

Stigler, J.W., \& Hiebert, J. (1999). The Teaching Gap: Best Ideas from the World's Teachers for Improving Education in the Classroom. New York: The Free Press.

Still, K., \& Bobis, J. (2005). The integration of mathematics and music in the primary school classroom. Proceedings of Annual Conference of the Mathematics Education Research Group of Australasia. Building Connections: Theory, Research and Practice, 712-719. Sydney, Australia: MERGA. Retrieved from: http://citeseerx.ist.psu.edu/viewdoc/download?doi=10.1.1.524.9937\&rep=rep1\&type=pdf

Tanaka, S. (2011). The notion of embodied knowledge. In P. Stenner, J. Cromby, J. Motzkau, J. Yen, \& Y. Haosheng (Eds.), Theoretical psychology: Global transformations and challenges (pp. 149-157). Concord: Captus Press. Retrieved from: https://www.researchgate.net/publication/316862553_The_notion_of_embodied_knowledge

Tejada, J., Gil, M. P., \& Pérez, R. G. (2011). Tactus: Didactic design and implementation of a pedagogically sound-based rhythm-training computer program. Journal of Music, Technology \& Education, 3(2-3), 155165. doi: 10.1386/jmte.3.2-3.155_1

Thayer, T., De la Cuadra, P., Tejada, J., Ledermann, R., Cádiz, R., \& Petrovich, M. (2012). An interdisciplinary approach for mathematical education based on musical metaphors. In J. Sánchez (ed.) Nuevas ideas en informática educativa [New ideas in educational software] (pp. 159-165). Santiago, Chile: Universidad de Chile.

Wu, H. (2008). Fractions, decimal, and Rational Numbers (Unpublished manuscript), University of California, Berqueley, CA. Retrieved from http://math.berkeley.edu/ wu/NMPfractions4.pdf 